\title{
Tissue adhesive in free gingival graft
}

\author{
Adesivo tecidual no enxerto gengival livre
}

Elton Gonçalves ZENÓBIO'

Elias Youssef Abou ABDALLAH'

Flávia Isabela BARBOSA'

Anna Cristina Petraccone CAIXETA'

Rodrigo Villamarim SOARES

\begin{abstract}
The aim of the present study was to review the literature regarding the utilization of 2-octyl cyanoacrylate's (Dermabond ${ }^{\circledR}$, Ethicon US, USA) as a tissue adhesive in dentistry; also, to report its use in the stabilization and fixation of a free gingival graft, indicated to increase the width of the keratinized attached mucosa at the lower incisive region. Literature analysis revealed numerous indications for this tissue adhesive in the medical field related to maxillofacial injuries. In dentistry, clinical reports, as well as controlled clinical studies conducted in humans and in animal models, using histological analysis described positive results for the use of different cyanoacrylate-based tissue adhesives. These studies reported that the use of tissue adhesives reduced the surgical procedure time period, eliminated postoperative visits as well as the discomfort of suture removal and, in addition, did not interfere with the clinical repair process. Favorable results, like the ones described in the literature, were obtained in the present case report using Dermabond ${ }^{\circledR}$.
\end{abstract}

Indexing terms: Cyanoacrylates. Tissue adhesives. Transplants.

\section{RESUMO}

O objetivo do presente estudo foi revisar a literatura pertinente sobre a utilização do 2-octil cianoacrilato (Dermabond ${ }^{\circledR}$, Ethicon US, USA) como adesivo tecidual na Odontologia, assim como relatar seu uso na estabilização e fixação de um enxerto gengival livre indicado para aumento da mucosa ceratinizada inserida na região dos incisivos inferiores. A análise da literatura revelou ampla aplicabilidade deste adesivo tecidual na área médica relacionada aos ferimentos maxilofaciais. Na Odontologia existem relatos clínicos e estudos controlados em humanos e em modelos animais, descrevendo resultados positivos, inclusive por meio da análise histológica, sobre a utilização de diferentes adesivos teciduais, à base do cianocrilato. Estes estudos relataram que o uso dos adesivos teciduais, reduz o tempo operatório, elimina visitas pós-operatórias, não apresenta o desconforto da remoção de suturas, além de não interferir no processo de reparo clínico. Resultados favoráveis como os descritos na literatura, foram obtidos no presente relato de caso com a utilização do Dermabond ${ }^{\circledR}$.

Termos de indexação: Cianoacrilato. Adesivos teciduais. Transplantes.

\section{INTRODUCTION}

The success of periodontal surgery depends on the appropriate coaptation of the incised edges, elimination of empty spaces and reduction of the amount of coagulation. In free gingival graft surgery, stabilization of the graft, hemostasis and cleansing of the site remain necessary ${ }^{1}$.

The suture is the most used and widespread technique for appropriate coaptation of the edges; however, new biomaterials and techniques are studied with the aim of uniting and maintaining the incised tissues stable and avoiding the penetration of foreign bodies. This favors the stabilization of the coagulation and provides esthetics to the surgical site ${ }^{2-5}$.
The use of cyanoacrylate-based adhesives in periodontal surgery, including free gingival grafts, has demonstrated ease and efficiency, minimizing the problems generated by suturing thread, and showing minimal toxicity and low $\cos ^{6-10}$. Thus, with the results described in the literature, it was considered appropriate to evaluate of the use of Dermabond ${ }^{\circledR}$ as a tissue adhesive for setting free gingival grafts ${ }^{11-12}$.

Binnie \& Forrest ${ }^{13}$ performed periodontal flaps, in the region of the second pre-molars and the incisors, on two six-month old dogs. They used sutures for coaptation on one side, and butyl-cyanoacrylate tissue adhesive on the other. They reported that the initial repair was faster

\footnotetext{
${ }^{1}$ Pontifícia Universidade Católica de Minas Gerais, Departamento de Odontologia. Av. Dom José Gaspar, 500/ Pr. 46, Coração Eucarístico, 30535-610, Belo Horizonte, MG, Brasil. Correspondência para / Correspondence to: EG ZENÓBIO. E-mail: <zenobio@pucminas.br>.
} 
using the adhesive, that the product was easy to apply, appropriate for setting the gingival flaps and that the histological exam showed no adverse effects.

Forrest ${ }^{14}$, in a longitudinal study, evaluated more than 300 patients undergoing periodontal surgery, including free gingival grafts, laterally and apically positioned flaps, rhizectomies, endodontic and exodontic surgery, in which butyl-cyanoacrylate was used for the coaptation of the edges. The results were compared with edges set using sutures. The adhesive was reported to promote rapid hemostasis and clinical repair similar to the sutures, was well accepted by the patients and there were no reports of local or systemic reactions. The application of the material to the posterior region was considered difficult but, in general, the use of the adhesive was reported to reduce operating time considerably when compared with suturing techniques.

One five-month study, comparing the tissue adhesive 2-octyl cyanoacrylate (Dermabondâ) to sutures in 136 lacerations of the face, hands and feet, was described ${ }^{15}$. The authors observed no significant differences between the two forms of coaptation in the repair of the wounds, and reported that Dermabond ${ }^{\circledR}$ has plasticizers in its composition that support its use in movable areas such as the face, skin over the joints, or in longer incisions. The authors also reported that the tested adhesive is effective in closing lacerations, in addition to taking less time to apply and being less painful than suturing.

Toriumi et al. ${ }^{16}$ submitted 111 patients to plastic facial procedures and compared the closing of the incisions using 2-octyl-cyanoacrylate to suturing. They observed that the time required for repair with sutures was approximately 4 times greater than with the adhesive. There was no incidence of dehiscence, hematoma or infection among the groups after one year; and, the esthetic results and patient satisfaction were superior in the 2-octyl-cyanoacryate group.

Barbosa et al. ${ }^{17}$ evaluated twenty-four subjects with gingival recession and absence of keratinized mucosa divided into two groups: free gingival grafts fixed with ethylcyanoacrylate (Group 1) and fixed with sutures (Group 2) to treatment. Probing depth, clinical attachment level, gingival recession, and dimensional changes of height and width were evaluated immediately post-operatively and at 15, 30, 45, and 90 days after surgery. They observed that dimensional changes related to the area of gingival graft were similar for both groups. The thickness of the gingival graft tissue influenced the dimensional changes in the height of the grafts in the recipient bed $(p<0.047)$. Gingival grafts, thinner than $1 \mathrm{~mm}$, showed a greater average height at the end of the study and with no significant changes regarding the total area of the graft. They conclude that the modality of gingival graft fixation did not present any significant influence over the clinical parameters evaluated.

\section{CASE REPORT}

The patient, a 42-year-old woman with no systemic alterations, was referred to the Department of Periodontics of the authors. Clinical examination revealed the absence of inserted keratinized mucosa in the region of the lower central incisors, the presence of inflammation and marginal edema and complaint of difficulty cleaning in the region. It was decided that a free gingival graft, attached using the tissue adhesive Dermabond ${ }^{\circledR}$, would be performed as part of the treatment in order to increase the amount of keratinized mucosa, facilitate cleaning and reestablish periodontal health. Four weeks prior to the surgical procedure, the patient underwent professional plaque control to prepare the region for the procedure.

During the initial evaluation, the following periodontal parameters were obtained: gingival bleeding index, probing depth (Figure 1), gingival recession, clinical attachment level, amount of keratinized mucosa (Figure 2) and amount of inserted keratinized mucosa.

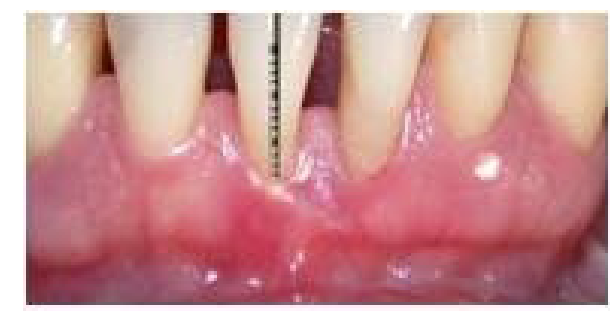

Figure 1. Pre-operative case (probing depth).

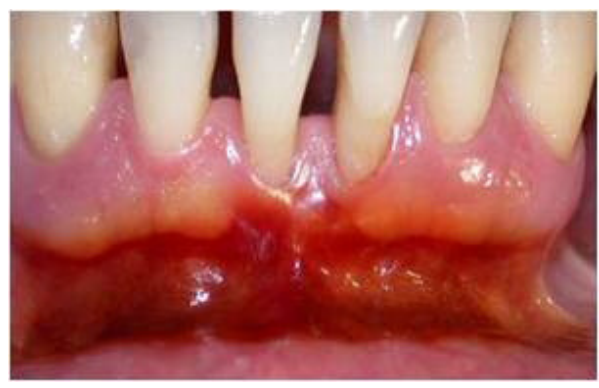

Figure 2. Pre-operative case (keratinized mucosa)

The following were used in the surgical procedure: rinse with a $0.12 \%$ chlorhexidine digluconate solution for one minute and anesthesia using 2\% lidocaine (1:100000) with vasoconstrictor. The surgical technique was performed 
according to standard form ${ }^{17-18}$, modified for the setting of the flap using Dermabond ${ }^{\circledR}$.

A Bard Parker no. 15C scalpel blade was used to perform the partial flap with a horizontal incision parallel to the long axis of the root, starting from the Mucogengival line to the base of the vestibule, extending to the mesial and distal, according to the width and height of the intended graft. Muscle inserts that could interfere with the stability of the graft were eliminated, maintaining a thin, smooth layer of conjunctive tissue to facilitate the correct adaptation of the graft. A perpendicular incision was made at the base of the vestibule to fenestrate the periosteum. A surgical guide having the same dimensions as the receiving area was created from sterile paper and placed in the region of the palate. Anesthesia was given by infiltration along the side of the guide, the incision was made around the guide and the graft was removed delicately. Adipose tissue and irregularities in the connective tissue were removed from the graft. The donor site was sutured using 4.0 silk threads and protected for seven days with surgical cement (Coe Packâ). The graft was placed in the recipient site and lightly pressed using sterile gauze soaked in sterile saline solution to reduce/eliminate clotting.

For setting with Dermabond ${ }^{\circledR}$, a new, sealed tube was used which was opened at the moment of the surgery. The contents were emptied into a sterile dappen dish, were immediately collected using a clinical probe (Figure 3) and taken to the surgical site, closing the edges of the gingival graft and the recipient site. With the graft properly adapted and coopted to the recipient site, traction and tension lip movements were performed to verify if there were any interference from muscle inserts that could cause movement in the graft (Figure 4). The patient received postoperative instructions related to careful cleaning of the region for 30 days with $0.12 \%$ chlorhexidine digluconate and the use of analgesics to reduce the initial pain.

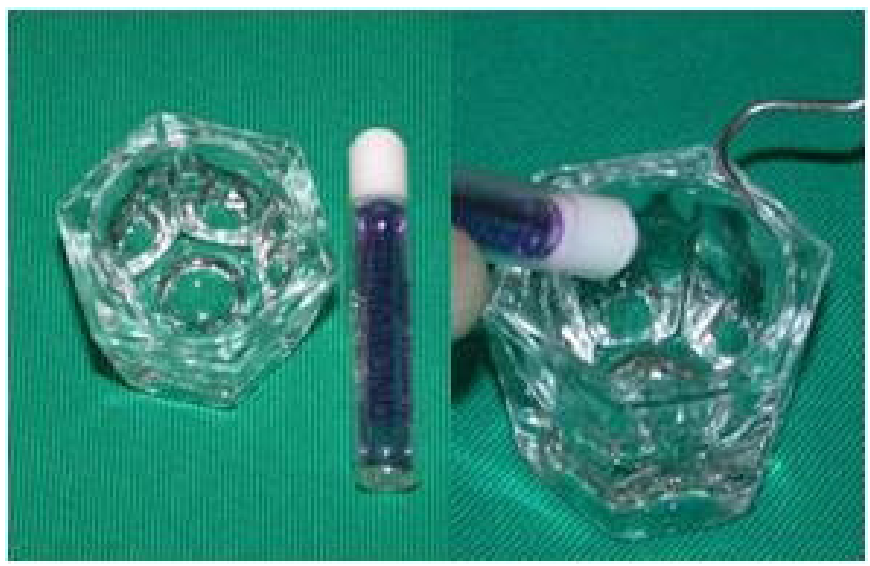

Figure 3. Tissular adhesive Dermabond ${ }^{\circledR}$

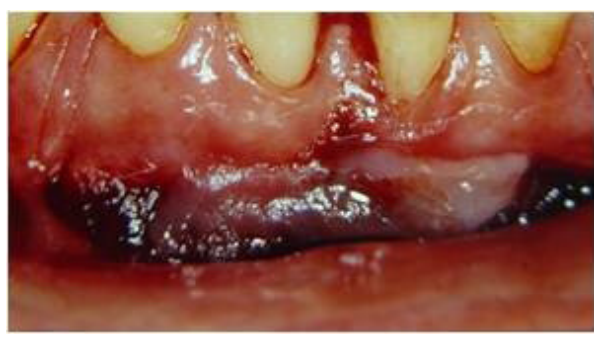

Figure 4. Immediate post-operative case.

At seven days the graft showed normal healing and absence of movement. The patient did not report, nor was there observed, any interference caused by the method of setting. At 15 days there was no edema and integration of the gingival graft with the adjacent tissues could be observed. At 30 days, the graft appeared clinically completely healed. A significant increase in the keratinized mucosa and the width of the gingival margin could be seen. The clinical observations of this period were similar to those verified at 90 and 180 days (Figures 5 and 6). All surgical procedures and the care of the patient were performed following the ethical principals contained in the Helsinki Declaration (2000), in addition to following the ANVISA standards for biosecurity and control.

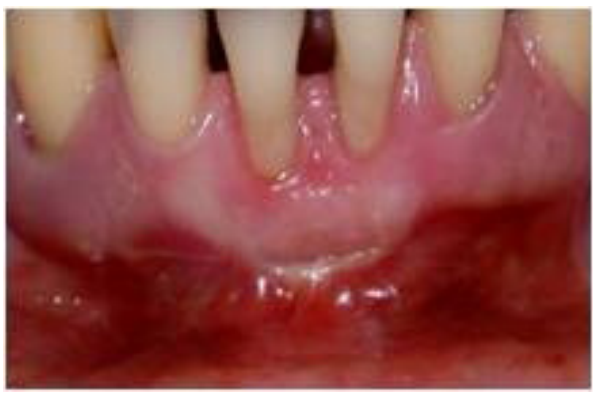

Figure 5. Final case (90 days).

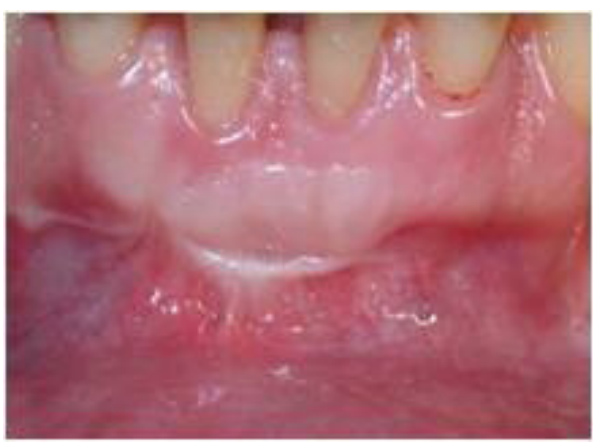

Figure 6. Final case (180 days).

\section{DISCUSSION}

The appropriate coaptation of the surgical edges determines the success of the procedures. Suturing is the technique most used; however, new biomaterials have 
been studied and proposed for this purpose. They maintain all the advantages of conventional suturing, favoring the stabilization of the blood clot and providing esthetics to the surgical site ${ }^{17-25}$.

The use of cyanoacrylate-based adhesives in periodontal surgery, including free gingival grafts, demonstrates ease and efficiency, minimizes the problems caused by suturing thread and shows minimal toxicity and low $\operatorname{cost}^{6-10,17}$.

The improvement of the periodontal clinical parameters, associated with the positive report of the patient as to the current ease of oral hygiene, reinforces the importance of the free gingival graft to increase the width of the gingival margin ${ }^{26}$ from the area of the inserted gingiva ${ }^{27-28}$ and for the maintenance of periodontal health.

\section{REFERÊNCES}

1. Hoexter DL. The sutureless free gingival graft. J Periodontol. 1979;50(2):75-8. doi:10.1902/jop.1979.50.2.75

2. Coover HN, Joyner FB, Sheerer NH. Chemistry and performance of cyanoacrylate adhesive. Spec J Tech Papers. 1959;5(1):413-7. doi:10.1055/s-2004-831406

3. Herod EL. Cyanoacrylates in dentistry: a review of the literature. J Can Dent Assoc. 1990;56(4):331-4

4. Doraiswamy NV, Baig $\mathrm{H}$, Hammett $\mathrm{S}$, Hutton M. Which tissue adhesive for wounds? Injury. 2003;35(8):636-7. doi:10.1016/ S0020-1383(02)00210-3

5. Toriumi DM, Bagal AA. Cyanoacrylate tissue adhesives for skin closure in the outpatient setting. Otolaryngol Clin North Am. 2002;35(1):103-18. doi:10.1016/S0030-6665(03)00097-5

6. Bhaskar SN, Frisch J, Margetis PM, Leonard F. Application of a new chemical adhesive in periodontic and oral surgery. Oral Surg Oral Med Oral Pathol. 1966;22:526-35.

7. Bhaskar SN, Frisch J, Cutright DE, Margetis PM. Effect of butyl cyanoacrylate on the healing of extraction wounds. Oral Surg Oral Med Oral Pathol. 1967;24(3):604-16. doi:10.1016/00304220(67)90200-9

8. Bhaskar SN, Beasley III JD, Cutright DE, Perez B. Free mucosal grafts in miniature swine and man. J Periodontol. 1971;42:32230. doi:10.1902/jop.1971.42.6.322

9. Lacaz Netto R, Macedo NL. Estudo clínico da reparação do enxerto gengival livre fixado por um adesivo à base de cianoacrilato. Rev Assoc Paul Cir Dent. 1986;40(2):164-70.

10. Santos GM, Lacaz Netto R, Santos LM, Okamoto T, Rocha RF Uso do Super-Bonder no reparo das feridas cirúrgicas. RGO - Rev Gaúch Odontol. 1990:38(6):435-9.

\section{CONCLUSION}

In the clinical case reported, the use of Dermabond ${ }^{\circledR}$ as the tissue adhesive for the setting and stabilization of the free gingival graft reduced the operating time and post-operative discomfort, eliminated the need for suture removal, did not interfere with the clinical repair process and, as reviewed in the literature, is suggested as an alternative to suturing in mucogingival surgery.

\section{Collaborators}

EG ZENOBIO, RV SOARES, EYA ABDALLAHM and ACP CAIXETA were responsible for guiding the development of the clinical case and writing the article.

11. Bhaskar SN, Frisch J, Margetis PM. Tissue response of rat tongue to hexyl, heptyl and octyl cyanoacrylate. Oral Surg Oral Med Oral Pathol. 1967;24(1):137-43. doi:10.1016/00304220(67)90300-3

12. Bhaskar SN, Frisch J. Use of cyanoacrylate adhesives in dentistry. J Am Dent Assoc. 1968;77(4):831-7.

13. Binnie $\mathbf{W H}$, Forrest JO. A study of tissue response to cyanoacrylate adhesive in periodontal surgery. J Periodontol. 1974;45(8):619-25.

14. Forrest JO. The use of cyanoacrilate in periodontal surgery. Periodontol. 1974;45(4):225-9.

15. Quinn J, Wells G, Sutcliffe T, Jarmuske M, Maw J, Stiell I, et al. A randomized trial comparing octylcyanoacrylate tissue adhesive and suturesinthemanagementoflacerations.JAMA. 1997;277(19):152730. doi:10.1001/jama.1997.03540430039030

16. Toriumi DM, O'Grady K, Desai D, Bagal A. Use of octyl-2cyanoacrylate for skin closure in facial plastic surgery. Plast Reconstr Surg. 1998;102(6):2209-19.

17. Barbosa Fl, Corrêa DS, Zenóbio EG, Costa FO, Shibli JA.Dimensional changes between free gingival grafts fixed with ethyl cyanoacrylate and silk sutures. J Int Acad Periodontol. 2009;11(2):170-6

18. Dorfman HS, Kennedy JE, Bird WC. Longitudinal evaluation of free autogenous gingival grafts. J Clin Periodontol. 1980;7(4):316-24.

19. Miller GM, Dannenbaum R, Cohen DW. A preliminary histologic study of the wound healing of mucogingival flaps when secured with the cyanoacrylate tissue adhesives. J Periodontol. 1974;45(8):608-18. Doi: 10.1902/jop.1974.45.8.2.608

20. Levin MP, Cutright DE, Bhaskar SN. Cyanoacrilates as a periodontal dressing. J Oral Med. 1975;30(2):40-3.

21. Javelet J, Torabinejad M, Danforth R. Isobutyl cyanoacrylate: a clinical and histologic comparison with sutures in closing mucosal incisions in monkeys. Oral Surg. 1985;59(1):91-4. 
22. Maw JL, Quinn JV, Wells GA, Ducic Y, Odell PF, Lamothe A, et al. A prospective comparison of cyanoacrylate tissue adhesive and suture for the closure of heas and neck incision. J Otolaryngol. 1997;26(1):26-30. doi:10.1001/archderm.137.9.1177

23. Quinn J, Maw J, Ramotar K, Wenckebach G, Wells G. Octyl cyanoacrylate tissue adhesive versus suture wound repair in a contaminated wound model. Surgery. 1997;122(1):69-72. doi:10.1016/S0039-6060(97)90266-X

24. Quinn J, Wells G, Sutcliffe T, Jarmuske M, Maw J, Stiell I, et al. A randomized trial comparing octylcyanoacrylate tissue adhesive and sutures in the management of lacerations. JAMA. 1997;277(19):1527-30.

25. Bruns TB, Robinson NS, Smith RJ, Kile DL, Davis TP, Sullivan KM, et al. A new tissue adhesive for laceration repair in children. J Pediatr. 1998;132(6):1067-70. doi:10.1016/S0022-3476(98)70415-9
26. Wennström JL. Lack of association between width of attached gingival and development of soft tissue recession-A 5-year longitudinal study. J Clin Periodontol. 1987;14(3):181-4. doi:10.1111/j.1600-051X.1987.tb00964.x

27. Yared KF, Zenóbio EG, Pacheco W. Periodontal status of mandibular central incisors after orthodontic proclination in adults. Am J Orth Dentofac Orthop. 2006;130(1):1-8. doi:10.1016/j. ajodo.2006.01.015

28. Maynard JG Jr, Wilson RD. Diagnosis and management of mucogingival problems in children. Dent Clin North Am. 1980;24:683-703

Received on: 13/8/2009

Final version resubmitted on: 15/10/2010

Approved on: 25/10/2010 
